\title{
PENGEMBANGAN WILAYAH PETERNAKAN SAPI POTONG BERBASIS KESESUAIAN FISIK LINGKUNGAN DAN KESESUAIAN LAHAN UNTUK PAKAN DI KABUPATEN CIANJUR
}

\section{The Regional Development of Cattle Based on Physical and Forage Land Suitability in Cianjur Regency}

\author{
Ema Suhaema1)*, Widiatmaka'), dan Boedi Tjahjono²) \\ 1) Alumni Program Studi Ilmu Perencanaan Wilayah, Sekolah Pascasarjana IPB, Jl. Raya Darmaga, Gedung Andi \\ Hakim Nasoetion Kampus IPB Darmaga Bogor 16680 \\ 2) Departemen Ilmu Tanah dan Sumberdaya Lahan, Fakultas Pertanian IPB, J1. Meranti Kampus IPB Darmaga \\ Bogor 16680
}

\begin{abstract}
The optimal physical environment for cattle can be reached in support of the suitability of ecological environment and the sufficiency of pasture or forage crops. Geographic Information Systems (GIS) was used in this research by analyzing the various digital maps (the landuse map, temperature map, soil map, elevation map, and rainfall map) and tabular databases for analyzing the physical land suitability, the suitability of forage and forage carrying capacity for livestock. The land which are physically suitable for grazing beef cattle in in Cianjur regency was 193,282 ha (53.45\% of the total area), while the unsuitable land was 3,076 ha (0.85\%). The area which was physically suitable for housed beef cattle was 112,877.71 ha (31.21\%), the land which was suitable but with Temperature Humidity Indexs (THI) as limiting factor was 60,616 ha (16.76\%), while the unsuitable area was 22,865 ha (6.32\%). The area which are suitable for cattle feed was 194,566 ha (53.80\%), while the unsuitable area was 1,792 ha (0.50\%). The area with forage carrying capacity in Cianjur regency which was categorized as safe was 186,479 ha (51.56\%), while the area which was categorized as vulnerable was 9,880 ha (2.73\%). The area for the development of grazing beef cattle were 126,626 ha (35.01\%) while the area for the development of housed beef cattle was 78,065 ha (21.59\%).
\end{abstract}

Keywords: Beef cattle, cattle feed, land suitability

\begin{abstract}
ABSTRAK
Kondisi fisik optimal ternak dapat dicapai bila didukung oleh kesesuaian lingkungan fisik tempat ternak tumbuh dan kecukupan hijauan sebagai makanan ternak. Analisis dalam penelitian ini dilakukan menggunakan Sistem Informasi Geografis (SIG) pada berbagai peta digital (peta pengunaan lahan, peta suhu, peta tanah, peta elevasi, dan peta curah hujan) dan datadata tabular untuk menilai kesesuaian fisik lingkungan, kesesuaian hijauan makanan ternak dan daya dukung hijauan makanan ternak. Luas kesesuaian fisik lingkungan untuk ternak sapi potong di Kabupaten Cianjur yang digembalakan adalah 193,282 hektar (ha) (53.45\% dari total luas wilayah), sedangkan lahan yang tidak sesuai 3,076 ha (0.85\%). Lahan yang sesuai secara fisik lingkungan untuk pengembangan sapi potong yang dikandangkan seluas 112,877 ha (31.21\%), lahan yang sesuai dengan pembatas Temperature Humidity Indexs (THI) seluas 60,616 ha (16.76\%) dan lahan yang tidak sesuai seluas 22,865 ha (6.32\%). Luas kesesuaian hijauan makanan ternak adalah 194,566 ha (53.80\%) dan luas lahan yang tidak sesuai adalah 1,792 ha $(0.50 \%)$. Daya dukung hijauan di Kabupaten Cianjur berada dalam kriteria aman seluas 186,479 ha (51.56\%) dan wilayah yang rawan pakan ternak seluas 9,880 ha $(2.73 \%)$. Wilayah untuk pengembangan peternakan sapi potong yang digembalakan di Kabupaten Cianjur seluas 126,626 ha (35.01\%) dan untuk pengembangan peternakan sapi potong yang dikandangkan seluas 78,065 ha $(21.59 \%)$.
\end{abstract}

Kata kunci: Sapi potong, pakan ternak, kesesuaian lahan

\section{PENDAHULUAN}

Ketersediaan pasokan daging di suatu wilayah umumnya terkait dengan jumlah dan produksi ternak di wilayah tersebut. Ternak memperlihatkan kondisi fisik optimal jika memiliki sifat genetik unggul, didukung oleh kesesuaian lingkungan dan kecukupan hijauan sebagai makanan ternaknya. Penempatan ternak pada suatu wilayah harus mempertimbangkan kesesuaian lahan, ketersediaan hijauan pakan ternak, limbah dari hasil pertanian dan sumber daya manusia yang terampil sebagai langkah yang strategis dalam memanfaatkan sumberdaya secara optimal serta mempertimbangkan kelestarian yang dilandasi pemahaman mendasar tentang sifat, karakteristik alami lahan dan perilaku ternak (Atmiyati, 2006). 
Kabupaten Cianjur dengan wilayah seluas 350,133 ha (BPS, 2012) memiliki peluang untuk pengembangan peternakan terutama ternak ruminansia. Hal ini ditunjang oleh wilayah yang sebagian besar luasnya (43.24\%) digunakan sebagai lahan pertanian (sawah, tegal/kebun dan ladang/huma) yang berpotensi untuk pengembangan peternakan, disamping lahan penggembalaan sendiri yang juga cukup luas, mencakup $11.84 \%$ dari luas wilayah. Dari penggunaan lahan yang ada, sebanyak $80.78 \%$ merupakan lahan yang berpotensi sebagai penyedia hijauan, yaitu berupa lahan pertanian, penggembalaan dan hutan. Berdasarkan data statistik dari Dinas Peternakan, Perikanan dan Kelautan Kabupaten Cianjur tahun 2006 sampai 2011, jumlah populasi ternak sapi potong di Kabupaten Cianjur mengalami peningkatan dari 23,319 ekor pada tahun 2006 menjadi 30,656 ekor pada tahun 2011. Dengan demikian selama kurun waktu empat tahun tersebut terjadi laju peningkatan populasi ternak rata-rata sebesar $5.20 \%$. Populasi ternak sapi potong tersebut tersebar di 32 kecamatan dengan konsentrasi terbesar di wilayah Cianjur bagian selatan (88.02\%). Pola pemeliharaan sapi potong di Kabupaten Cianjur ada dua jenis, yaitu sapi yang digembalakan pada wilayah yang melakukan budidaya (pembibitan) dan sapi yang dikandangkan pada wilayah yang melakukan penggemukan.

Kabupaten Cianjur secara geografis dapat dikelompokkan dalam tiga wilayah, yaitu Cianjur bagian utara, Cianjur bagian tengah, dan Cianjur bagian selatan. Wilayah Cianjur bagian utara sebagian besar berupa pegunungan dengan ketinggian 450-2,962 $\mathrm{m}$ di atas permukaan laut, dan sebagian merupakan dataran yang digunakan untuk perkebunan dan persawahan. Wilayah Cianjur bagian tengah merupakan wilayah perbukitan yang secara umum mempunyai tanah yang labil dan rentan terhadap longsor dan dataran rendah yang digunakan untuk persawahan dan perkebunan. Wilayah Cianjur bagian selatan merupakan dataran rendah dengan penggunaan lahan utama perkebunan dan persawahan, diselingi oleh bukit-bukit kecil yang labil dan rawan terhadap longsor yang berbatasan dengan Samudra Indonesia. Adanya tiga karakter wilayah yang berbeda ini berpengaruh terhadap kondisi fisik wilayah dan sosial-ekonomi masyarakat. Faktor iklim dan topografi diantaranya curah hujan, suhu dan kelerengan berpengaruh terhadap kemampuan wilayah untuk mendukung pengembangan sapi potong dan daya dukung hijauan di Kabupaten Cianjur.

Dengan latar belakang tersebut, tujuan penelitian ini adalah untuk mengetahui kesesuaian fisik lingkungan untuk pengembangan ternak sapi potong dan daya dukung hijauan makanan ternak di Kabupaten Cianjur.

\section{BAHAN DAN METODE}

Data peta yang digunakan berupa Peta Sumberdaya Tanah Pulau Jawa dan Madura (Puslitanak, 2011), Peta Penggunaan Lahan (Bappeda, 2011), Peta Rencana Tata Ruang Wilayah (RTRW) Kabupaten Cianjur (Bappeda, 2011), peta kelerengan, peta curah hujan, dan peta tanah (Bappeda, 2011). Pengukuran kualitas air dan pengecekan lapangan dilakukan untuk mengetahui kondisi eksisting wilayah-wilayah terpilih dengan metode stratified random sampling.

\section{Kesesuaian Fisik Lingkungan Peternakan Sapi Potong}

Penilaian kesesuaian fisik lingkungan dilakukan menggunakan kriteria yang dikompilasi dari berbagai sumber sebagaimana disajikan pada Tabel 1. Parameter yang digunakan adalah kelompok parameter temperatur (suhu, kelembaban, dan Temperature Humidity Indexs/THI), ketersediaan air, kualitas air dan kondisi terrain. Operasi tumpangsusun (overlay) secara spasial dilakukan terhadap peta-peta digital menggunakan Sistem Informasi Geografis (SIG). Metode matching (Hardjowigeno dan Widiatmaka, 2007) dilakukan antara unsur-unsur fisik lahan di Kabupaten Cianjur berdasarkan pembatas minimum.

Tabel 1. Kriteria penilaian kesesuaian lingkungan fisik lingkungan untuk ternak sapi dengan sistem pemeliharaan digembalakan dan dikandangkan

\begin{tabular}{|c|c|c|c|c|}
\hline \multirow[t]{2}{*}{ Parameter } & \multicolumn{2}{|c|}{$\begin{array}{c}\begin{array}{c}\text { Kesesuaian untuk sapi yang } \\
\text { digembalakan }\end{array} \\
\end{array}$} & \multicolumn{2}{|c|}{$\begin{array}{c}\begin{array}{c}\text { Kesesuaian untuk sapi yang } \\
\text { dikandangkan }\end{array} \\
\end{array}$} \\
\hline & $\mathbf{S}$ & $\mathbf{N}$ & $\mathbf{S}$ & $\mathbf{N}$ \\
\hline \multicolumn{5}{|l|}{ Temperatur $(t)$} \\
\hline - Suhu rata-rata $\left({ }^{\circ} \mathrm{C}\right)^{\mathrm{a}}$ & $18-37$ & $<18 ;>37$ & - & - \\
\hline - Kelembaban $(\%)^{\mathrm{a}}$ & $60-90$ & $<60 ;>90$ & - & - \\
\hline - THI (n) $)^{\mathrm{b}}$ & - & - & $70-80$ & $<70 ;>80$ \\
\hline \multicolumn{5}{|l|}{ Ketersediaan Air $(\mathbf{w})^{\mathrm{a}}$} \\
\hline - Bulan Kering $(<100 \mathrm{~mm})^{\mathrm{c}}$ & $<8$ bulan & $>8$ bulan & $<8$ bulan & $>8$ bulan \\
\hline - Curah hujan $\operatorname{tahun}^{-1}(\mathrm{~mm})^{\mathrm{d}}$ & $750-4,000$ & $<750 ;>4,000$ & $<4.000$ & $>4,000$ \\
\hline - Keberadaan sumber air* & Ada & Tidak ada & Ada & Tidak ada \\
\hline \multicolumn{5}{|l|}{ Kualitas Air $(\mathbf{q})^{\mathbf{a}}$} \\
\hline$-\mathrm{pH}$ air & $6.5-9.0^{\mathrm{b}}$ & $<6.5 ;>9.0^{\mathrm{b}}$ & $6.5-9.0$ & $<6.5 ;>9.0$ \\
\hline \multicolumn{5}{|l|}{ Terrain (s) } \\
\hline - Kelerengan $(\%)^{\mathbf{e}}$ & $<40$ & $>40$ & $<40$ & $>40$ \\
\hline
\end{tabular}

\section{Kesesuaian Lahan untuk Hijauan Makanan Ternak}

Kesesuaian lahan untuk setiap jenis hijauan makan ternak (rumput Gajah, rumput Setaria sp., dan
Leguminaceae/leguminosa) mengikuti kriteria yang dikeluarkan oleh Pusat Penelitian dan Pengembangan Tanah dan Agroklimat Bogor (Djaenudin et al., 2003). Kriteria kesesuaian lahan untuk penggembalaan (pasture) 
dianalisis menggunakan kriteria menurut Hardjowigeno dan Widiatmaka (2007).

Analisis dilakukan menggunakan software SIG pada peta-peta digital yang terkoreksi. Overlay dilakukan pada peta administrasi, peta tematik (suhu, curah hujan, lereng, dan tekstur), dan peta penggunaan lahan di Kabupaten Cianjur sehingga didapatkan peta satuan lahan untuk hijauan makanan ternak. Selanjutnya dilakukan matching antara peta satuan lahan dengan kriteria kesesuaian hijauan lahan untuk setiap jenis hijauan makan ternak (rumput gajah, rumput Setaria sp., leguminosa, dan rumput alam/pastura) sehingga dihasilkan peta kesesuaian lahan untuk setiap jenis hijauan makanan ternak di Kabupaten Cianjur. Dari masing-masing kesesuaian jenis hijauan, dilakukan analisis overlay union untuk menggabungkan peta kesesuaian empat jenis hijauan makanan ternak yang dianalisis.

\section{Daya Dukung Hijauan Makanan Ternak}

Untuk mengetahui ketersediaan dan daya dukung hijauan makanan ternak, digunakan data populasi ternak sapi potong, data luas penggunaan lahan dan produksi tanaman pangan (BPS, 2012). Analisis dilakukan untuk menghitung kebutuhan pakan minimum ternak ruminansia per satu satuan ternak (1 ST), menggunakan rumus Thahar dan Mahyudin (1993) (dengan modifikasi) sebagai berikut:

\section{$\mathrm{K}=2.5 \% \times 50 \% \times 365 \times 200 \mathrm{~kg}=0.9125$ ton $\mathrm{BKC} \operatorname{tahun}^{-1} \mathrm{ST}^{-1}$}

(Keterangan: K: Kebutuhan pakan minimum untuk 1 ST dalam ton bahan kering tercerna atau DDM (digestible dry matter) selama satu tahun; 2.5 $\%$ : Kebutuhan minimum jumlah ransum hijauan pakan (bahan kering) terhadap berat badan; $50 \%$ : Nilai rata-rata daya cerna berbagai jenis tanaman; 365: Jumlah hari dalam 1 tahun; $200 \mathrm{~kg}$ : Berat hidup 1 ST di Kabupaten Cianjur; BKC: Berat kering cerna)

Produksi bahan kering merupakan jumlah dari produksi pakan asal limbah pertanian dan produksi pakan dari hijauan alami. Jumlah potensi limbah dari masingmasing tanaman pangan merupakan potensi ketersediaan pakan potensial saat ini. Potensi limbah dihitung dari sisa hasil produksi tanaman pangan seperti jerami padi sawah, padi ladang, jagung, kacang kedelai, kacang hijau, kacang tanah, ubi jalar, dan ubi kayu. Potensi hijauan alami dihitung dari luas perkebunan dan luas penggunaan lahan seperti pekarangan, tegalan, huma, ladang, kebun, lahan bera, penggembalaan, hutan rakyat, luas perkebunan (luas tanaman kelapa dalam dan luas perkebunan karet), dan lainnya. Perhitungan pakan asal limbah pertanian dan hijauan alami per kecamatan dihitung dengan rumus menurut Ashari et al. (1996) sebagai berikut:

Potensi limbah $=(\mathrm{ps} \times 0.4)+(\mathrm{pl} \times 3 \times 0.4)+(\mathrm{jg} \times 3 \times 0.5)+(\mathrm{kd}$ $\mathrm{x} 3 \times 0.55)+\{(\mathrm{kh}+\mathrm{kt}) \times 2 \times 0.55\}+\{(\mathrm{uj} \times 0.25 / 6)+(\mathrm{uk} \times$ $0.25 / 4)\} \times 0.65$

(Keterangan: ps: padi sawah; pl: padi ladang; jg: jagung; kd: kedelai; kh: kacang hijau; kt: kacang tanah; uj: ubi jalar; uk: ubi kayu)
Potensi hijauan alami $=\{($ pkarang $\times 0.53 \times 2)+($ teg. + huma + lad + kebun + l.bera) $\times 2.875)+($ penggem $\times 0.75))+($ Hryt $\times 0.6)$ $+($ lain $x$ 0.75) $+($ Lkld x 10) $+($ Lkrt x 2$)+($ Lkst x 5) $+($ Lckh $x$ 5)\} $\times 0.5$

(Keterangan: pkarang: pekarangan; teg: tegalan, huma; lad: ladang, kebun; L.bera: lahan bera, penggembalaan; Hryt: hutan rakyat, lain-lain; Lkld: luas tanaman kelapa dalam; Lkrt: luas tanaman karet; Lkst: luas tanaman kelapa sawit; Lckh: luas tanaman cengkeh)

Tingkat keamanan pakan ternak pada suatu wilayah diukur dengan Indeks Daya Dukung Ternak (IDD). Analisa daya dukung dilakukan pada satuan wilayah administrasi kecamatan. IDD dihitung dengan persamaan sebagai berikut (Ashari et al., 1996):

IDD $=\frac{\text { Total Produksi BK }(\mathrm{kg})}{\text { Jumlah Populasi (ST) x Kebutuhan BK }\left(\mathrm{kg} \mathrm{ST}^{-1}\right)}$

Nilai IDD merupakan nilai-nilai yang menunjukkan standar kriteria daya dukung hijauan makanan ternak. Adapun kriterianya adalah: kritis (IDD<1), rawan (IDD antara 1-2), dan aman (IDD>2).

\section{Wilayah yang Sesuai untuk Pengembangan Ternak}

Untuk mengetahui wilayah yang sesuai untuk pengembangan ternak sapi potong yang digembalakan dilakukan overlay antara peta kesesuaian fisik lingkungan untuk ternak yang digembalakan, peta kesesuaian hijauan makanan ternak dan peta daya dukung/ketersediaan hijauan makanan ternak dihasilkan peta wilayah pengembangan ternak sapi potong yang digembalakan. Demikian pula halnya untuk mengetahui wilayah yang sesuai untuk pengembangan ternak sapi potong yang dikandangkan dilakukan overlay antara peta kesesuaian fisik lingkungan untuk ternak yang dikandangkan, peta kesesuaian hijauan makanan ternak dan peta daya dukung/ketersediaan hijauan makanan ternak sehingga dihasilkan peta wilayah pengem-bangan ternak sapi potong yang dikandangkan.

\section{HASIL DAN PEMBAHASAN}

\section{Kesesuaian Fisik Lingkungan untuk Peternakan Sapi Potong yang Digembalakan dan Dikandangkan}

Hasil analisis kesesuaian fisik lingkungan ternak sapi potong yang digembalakan disajikan pada Tabel 2 . Hasil tersebut menunjukkan bahwa sebagian besar lahan yaitu 193,282 ha $(53.45 \%)$ sesuai (S) untuk peternakan sapi potong, sedangkan lahan yang tidak sesuai $(\mathrm{N})$ seluas 3,076 ha $(0.85 \%)$. Wilayah yang sesuai untuk peternakan sapi potong dengan pola penggembalaan dominan berada di Cianjur bagian selatan, yaitu seluas 102,992 ha $(28.48 \%)$. Sebaran kesesuaian fisik lingkungan untuk sapi potong yang digembalakan disajikan pada Gambar 1a. 
Tabel 2. Luas kesesuaian lahan untuk sapi potong yang digembalakan di Kabupaten Cianjur

\begin{tabular}{|c|c|c|c|c|}
\hline \multirow{2}{*}{$\begin{array}{l}\text { Wilayah } \\
\text { pengembangan }\end{array}$} & \multicolumn{3}{|c|}{ Luas lahan (ha)* } & \multirow{2}{*}{ Jumlah (ha)* } \\
\hline & $\mathbf{S}$ & $\mathbf{N}$ & TD & \\
\hline Utara & $51,686.07(14.29 \%)$ & $442.77(0.12 \%)$ & $56,106.4(15.51 \%)$ & $108,235.25$ \\
\hline Tengah & $38,604.22(10.67 \%)$ & $2,634.16(0.73 \%)$ & $64,666.25(17.88 \%)$ & $105,904.63$ \\
\hline Selatan & $102,992.33(28.48 \%)$ & - & $44,514.95(12.31 \%)$ & $147,507.28$ \\
\hline Jumlah (ha)* & $193,282.62(53.45 \%)$ & $3,076.94(\mathbf{0 . 8 5 \%})$ & $165,287.60(45.70 \%)$ & $361,647.15$ \\
\hline
\end{tabular}

*Luas merupakan penghitungan luas dari peta digital; S:Sesuai; N:Tidak sesuai; TD:Tidak dinilai

Hasil analisis kesesuaian lingkungan fisik untuk ternak sapi yang dikandangkan disajikan pada Tabel 3, sedangkan sebaran lahannya ditunjukkan pada Gambar 1b. Lingkungan fisik yang sesuai (S) pemeliharaan sapi potong yang dikandangkan seluas 112,877 ha $(31.21 \%)$, lahan yang sesuai dengan pembatas indeks kelembaban udara (Temperature Humidity Index/THI) (S-n) seluas 60,616 ha $(16.76 \%)$ dan lahan yang tidak sesuai $(\mathrm{N})$ seluas 22,865 ha $(6.32 \%)$.

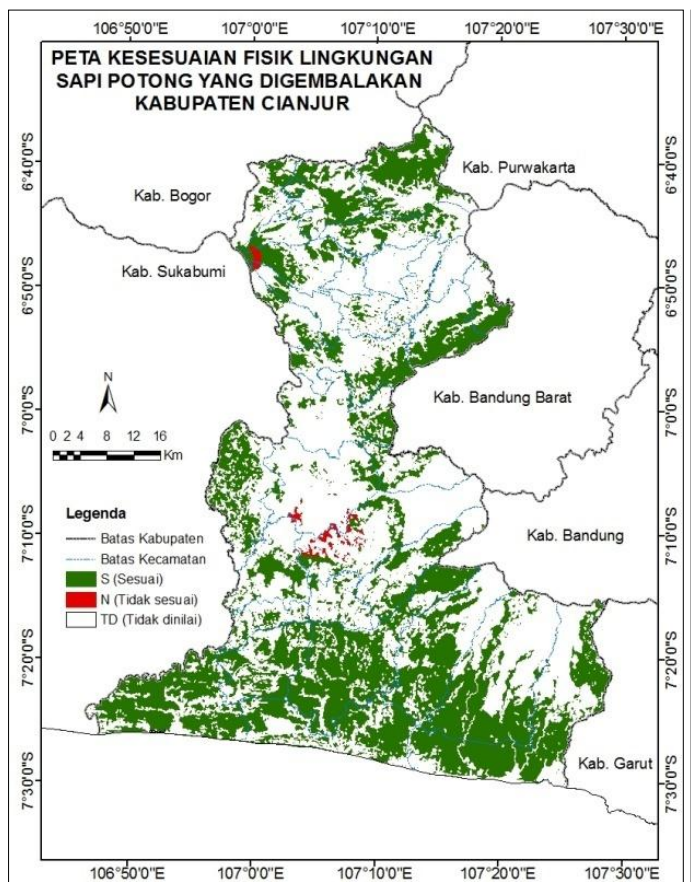

(a) Sapi potong yang digembalakan

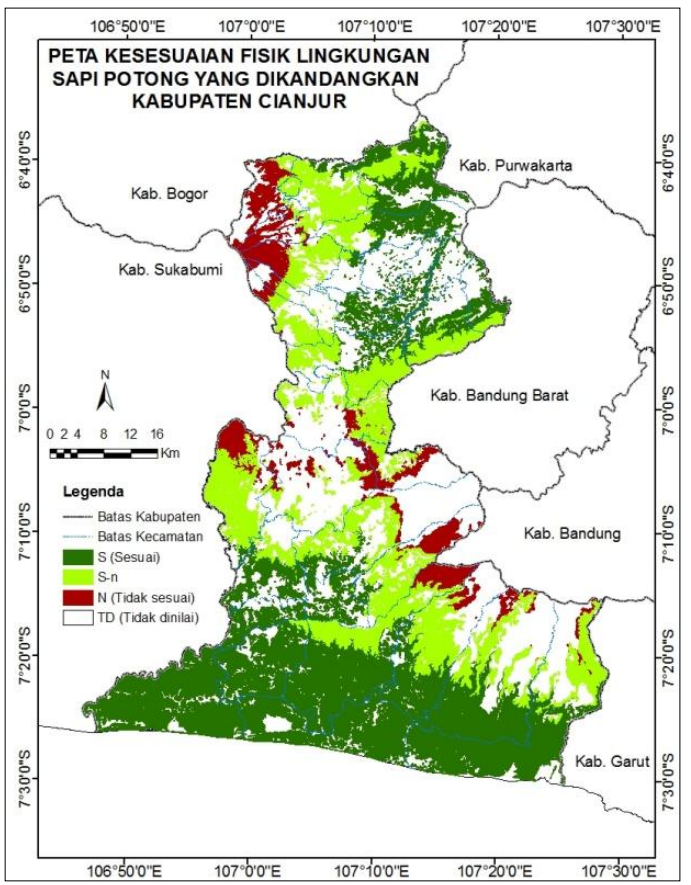

(b) Sapi potong yang dikandangkan

Gambar 1. Peta kesesuaian fisik lingkungan untuk ternak sapi potong; (a) yang digembalakan; (b) yang dikandangkan

Tabel 3. Luasan kesesuaian lahan untuk sapi potong yang dikandangkan di Kabupaten Cianjur

\begin{tabular}{|c|c|c|c|c|c|}
\hline \multirow{2}{*}{$\begin{array}{l}\text { Wilayah } \\
\text { pengembangan }\end{array}$} & \multicolumn{4}{|c|}{ Luas lahan (ha) } & \multirow{2}{*}{ Jumlah (ha)* } \\
\hline & $\mathbf{S}$ & S-n & $\mathbf{N}$ & TD & \\
\hline Utara & $\begin{array}{r}21,424.22 \\
(5.92 \%)\end{array}$ & $\begin{array}{r}22,993.07 \\
(6.36 \%)\end{array}$ & $\begin{array}{l}7,711.55 \\
(2.13 \%)\end{array}$ & $\begin{array}{r}56,106.41 \\
(15.51 \%)\end{array}$ & $108,235.25$ \\
\hline Tengah & $\begin{array}{r}10,812.04 \\
(12.38 \%)\end{array}$ & $\begin{array}{r}20,197.76 \\
(5.47 \%)\end{array}$ & $\begin{array}{r}10,228.58 \\
(9.38 \%)\end{array}$ & $\begin{array}{r}64,666.25 \\
(2.05 \%)\end{array}$ & $105,904.63$ \\
\hline Selatan & $\begin{array}{r}80,641.45 \\
(22.30 \%)\end{array}$ & $17,425.82(4.82 \%)$ & $\begin{array}{r}4,925.07 \\
(1.36 \%)\end{array}$ & $\begin{array}{r}44,514.95 \\
(12.31 \%)\end{array}$ & $147,507.28$ \\
\hline Jumlah (ha)* & $\begin{array}{r}112,877.71 \\
(31.21 \%)\end{array}$ & $\begin{array}{l}60,616.65 \\
(16.76 \%)\end{array}$ & $\begin{array}{r}22,865.20 \\
(6.32 \%)\end{array}$ & $\begin{array}{r}165,287.60 \\
(45.70 \%)\end{array}$ & $361,647.15$ \\
\hline
\end{tabular}

*Luas merupakan penghitungan luas dari peta digital; S:Sesuai; S-n:Sesuai dengan pembatas THI; N:Tidak sesuai; TD:Tidak dinilai

Ditinjau dari faktor iklim, wilayah Kabupaten Cianjur memiliki curah hujan yang berkisar antara 2,0004,500 mm tahun ${ }^{-1}$, variasi temperatur udara berkisar 20.3$26.3^{\circ} \mathrm{C}$, nilai THI berkisar antara $68-78$, dan kelerangan antara $0->40 \%$. Faktor iklim yang berpengaruh pada pemeliharaan sapi potong yang digembalakan adalah curah hujan dan kelerengan. Intensitas curah hujan yang tinggi $\left(>4,000\right.$ mm tahun $\left.^{-1}\right)$ dan kelerengan $>15 \%$ mempengaruhi kesesuaian hijauan yang tumbuh di padang penggembalaan/pastura. Hal tersebut berpengaruh terhadap ketersediaan/daya dukung hijauan sebagai pakan ternak yang berada di penggembalaan. Dalam pola penggembalaan, kontinuitas ketersediaan hijauan di padang penggembalaan menjadi hal yang penting.

Dalam pola pemeliharaan ternak sapi potong yang dikandangkan, faktor Temperature Humidity Index (THI) menjadi pembatas yang penting selain curah hujan dan kelerengan. Nilai THI terkait dengan pengaruh stress akibat panas pada ternak. Ternak yang dikandangkan harus beradaptasi dengan desain kandang karena ukuran tinggi dan lebar kandang dan luas bukaan ventilasi kandang sangat berpengaruh terhadap suhu di dalam kandang (Yani 
et al., 2007). Sapi potong yang dikandangkan rentan mengalami stress panas dibandingkan dengan sapi yang digembalakan karena terbatasnya lingkungan tempat distribusi panas tubuh sapi potong.

\section{Kesesuaian Lahan untuk Hijauan Makanan Ternak}

Kesesuaian lahan untuk hijauan makanan ternak yang dianalisis merupakan gabungan (overlay union) dari kesesuaian rumput Gajah, Setaria spachelata, rumput alam/pastura, dan leguminosa. Kesesuaian lahan dianalisis pada tingkat ordo yaitu $\mathrm{S}$ (sesuai) dan $\mathrm{N}$ (tidak sesuai). Hasil analisis spasial untuk hijauan makanan ternak di Kabupaten Cianjur disajikan pada Gambar 2a.

Sebaran kesesuaian lahan untuk hijauan makanan ternak terdapat di wilayah Cianjur bagian selatan seluas 102,708 ha $(28.40 \%)$ meliputi Kecamatan Agrabinta, Cibinong, Cidaun, Cikadu, Leles, dan Sindangbarang.
Pada wilayah Cianjur bagian tengah, lahan yang sesuai seluas 41,238 ha (11.40\%) meliputi Kecamatan Campaka, Campakamulya, Cijati, Kadupandak, Pagelaran, Pasirkuda, Sukanagara, Takokak, dan Tanggeung. Lahan yang sesuai untuk hijauan makanan ternak di wilayah Cianjur bagian utara seluas 50,619 ha $(14.00 \%)$ meliputi Kecamatan Bojongpicung, Cianjur, Cibeber, Cikalongkulon, Cilaku, Ciranjang, Haurwangi, Karangtengah, Mande, Sukaluyu, dan Sukaresmi. Tabel 4 menunjukkan bahwa total luas lahan yang sesuai (S) untuk hijauan makanan ternak di Kabupaten Cianjur adalah 194,566 ha (53.80\%), sedangkan lahan yang tidak sesuai $(\mathrm{N})$ adalah 1,792 ha $(0.50 \%)$. Berdasarkan hal ini dapat dinyatakan bahwa Kabupaten Cianjur sesuai untuk penanaman empat jenis hijauan makanan ternak yaitu rumput Gajah, Setaria sp., leguminosa dan pastura.

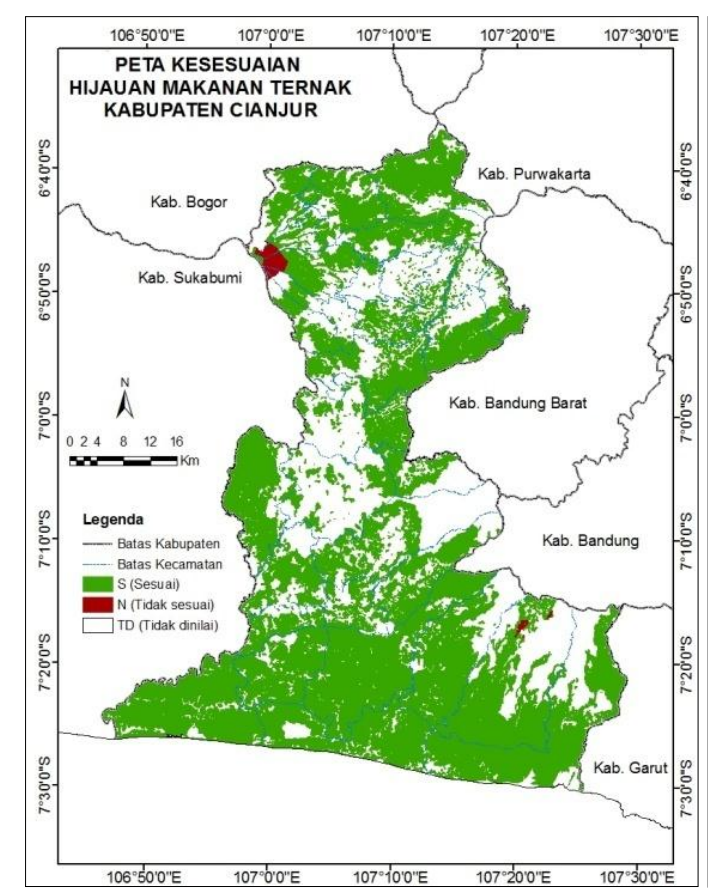

(a) Kesesuaian hijauan makanan ternak

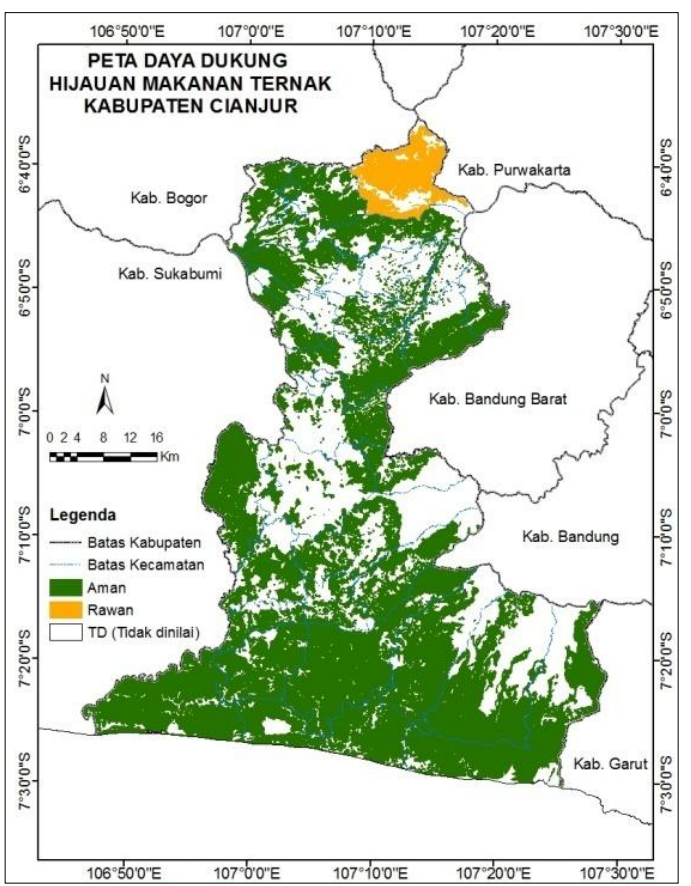

(b) Daya dukung hijauan makanan ternak

Gambar 2. Peta kesesuaian dan daya dukung hijauan makanan ternak; (a) kesesuaian hijauan makanan ternak; (b) daya dukung hijauan makanan ternak

Tabel 4. Luas kesesuaian lahan untuk hijauan makanan ternak di Kabupaten Cianjur

\begin{tabular}{|c|c|c|c|c|}
\hline \multirow{2}{*}{$\begin{array}{l}\text { Wilayah } \\
\text { pengembangan }\end{array}$} & \multicolumn{3}{|c|}{ Luas lahan (ha)* } & \multirow{2}{*}{ Jumlah (ha)* } \\
\hline & $\mathbf{S}$ & $\mathbf{N}$ & TD & \\
\hline Utara & $50,619.77(14.00 \%)$ & $1,509.07(0.42 \%)$ & $56,106.41(15.51 \%)$ & $108,235.25$ \\
\hline Tengah & $41,238.38(11.40 \%)$ & & $64,666.25(17.88 \%)$ & $105,904.63$ \\
\hline Selatan & $102,708.80(28.40 \%)$ & $283.54(0.08 \%)$ & $44,514.95(12.31 \%)$ & $147,507.28$ \\
\hline Jumlah (ha)* & $194,566.95(53.80 \%)$ & $1,792.61(0.50 \%)$ & $165,287.60(45.70 \%)$ & $361,647.15$ \\
\hline
\end{tabular}

*Luas merupakan penghitungan luas dari peta digital; S:Sesuai; N:Tidak sesuai; TD:Tidak dinilai

\section{Daya Dukung Hijauan Makanan Ternak dan Kapasitas Tampung Lahan untuk Pengembangan Sapi Potong}

Dalam pengembangan wilayah, lingkungan fisik yang sesuai perlu didukung ketersediaan hijauan untuk pakan ternak. Jumlah produksi hijauan suatu wilayah terkait dengan kapasitas tampung ternak. Hasil analisis daya dukung hijauan makanan ternak adalah aman di 31 kecamatan di Kabupaten Cianjur dan hanya Kecamatan Cikalongkulon yang memiliki tingkat keamanan pakan dalam status rawan. Status daya dukung hijauan di Kabupaten Cianjur adalah aman pada luasan sebesar 186,479 ha $(51.56 \%)$ (Tabel 5) dan sebaran lahannya ditunjukkan pada Gambar 2b. Hal ini mengindikasikan bahwa wilayah tersebut dapat menyediakan hijauan secara cukup untuk pertumbuhan sapi potong. 
Tabel 5 menunjukkan bahwa beberapa wilayah di Cianjur bagian utara merupakan wilayah dengan status daya dukung rawan. Wilayah tersebut adalah Kecamatan Cikalongkulon yang memiliki jumlah ternak sapi potong terbanyak (14,597 ekor dari total 112,811 ekor pada tahun 2011), sehingga wilayah ini hanya mampu menampung ternak sebanyak 2 ST ha ${ }^{-1}$.

Tabel 5. Luas status daya dukung hijauan makanan ternak di Kabupaten Cianjur

\begin{tabular}{|c|c|c|c|c|}
\hline \multirow{2}{*}{$\begin{array}{c}\text { Wilayah } \\
\text { pengembangan }\end{array}$} & \multicolumn{3}{|c|}{ Luas lahan (ha) } & \multirow{2}{*}{ Jumlah (ha)* } \\
\hline & Aman & Rawan & TD & \\
\hline Utara & $42,248.73(11.68 \%)$ & $9,880.11(2.73 \%)$ & $56,106.4(15.51 \%)$ & $108,235.25$ \\
\hline Selatan & $102,992.33(28.48 \%)$ & - & $44,514.95(12.31 \%)$ & $147,507.28$ \\
\hline Jumlah (ha)* & $186,479.45(51.56 \%)$ & $9,880.11(2.73 \%)$ & $165,287.60(45.70 \%)$ & $361,647.15$ \\
\hline
\end{tabular}

*Luas merupakan penghitungan luas dari peta digital;TD: Tidak dinilai

\section{Pengembangan Peternakan Sapi Potong Berbasis Kesesuaian Fisik Lingkungan dan Hijauan Makanan Ternak di Kabupaten Cianjur}

Hasil analisis kesesuaian fisik lingkungan dan hijauan makanan ternak di Kabupaten Cianjur disajikan pada Tabel 6, Tabel 7, dan Gambar 3. Wilayah pengembangan peternakan sapi potong adalah wilayah yang sesuai secara fisik lingkungan, sesuai untuk hijauan makanan ternak dan tingkat ketersediaan hijauan berada pada status aman. Tabel 6 menunjukkan luasan wilayah untuk pengembangan peternakan sapi potong yang digembalakan dominan berada di wilayah Cianjur bagian selatan seluas 71,129 ha $(19.67 \%)$.

Tabel 7 menunjukkan pengembangan peternakan untuk sapi potong yang dikandangkan. Wilayah yang sesuai untuk pengembangan peternakan sapi potong yang dikandangkan dominan berada di wilayah Cianjur bagian selatan seluas 59,430 ha $(16.43 \%)$.

Tabel 6. Luas wilayah pengembangan sapi potong yang digembalakan di Kabupaten Cianjur

\begin{tabular}{|c|c|c|c|c|}
\hline \multirow{2}{*}{$\begin{array}{l}\text { Wilayah } \\
\text { pengembangan }\end{array}$} & \multicolumn{3}{|c|}{ Luas lahan (ha)* } & \multirow{2}{*}{ Jumlah (ha)* } \\
\hline & $\mathbf{S}$ & $\mathbf{N}$ & TD & \\
\hline Utara & $27,623.71(7.64 \%)$ & $24,505.13(6.78 \%)$ & $56,106.41(15.51 \%)$ & $108,235.25$ \\
\hline Tengah & $27,873.19(7.71 \%)$ & $13,365.19(3.70 \%)$ & $64,666.25(17.88 \%)$ & $105,904.63$ \\
\hline Selatan & $71,129.09(19.67 \%)$ & $31,863.24(8.81 \%)$ & $44,514.95(12.31 \%)$ & $147,507.28$ \\
\hline Jumlah(ha)* & $126,626.00(35.01 \%)$ & $69,733.56(19.28 \%)$ & $165,287.60(45.70 \%)$ & $361,647.15$ \\
\hline
\end{tabular}

*Luas merupakan penghitungan luas dari peta digital; S:Sesuai; N:Tidak sesuai; TD:Tidak dinilai

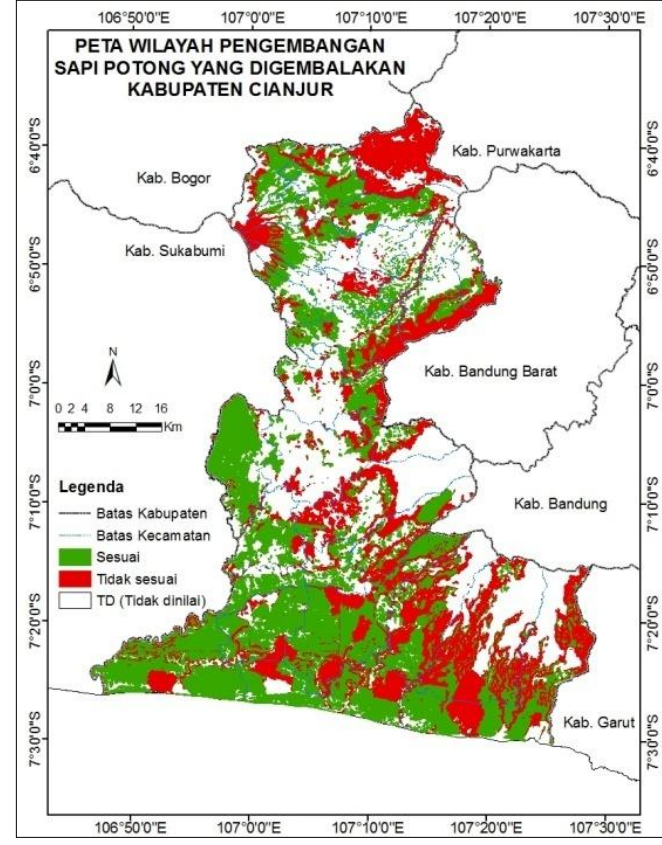

(a) Ternak yang digembalakan

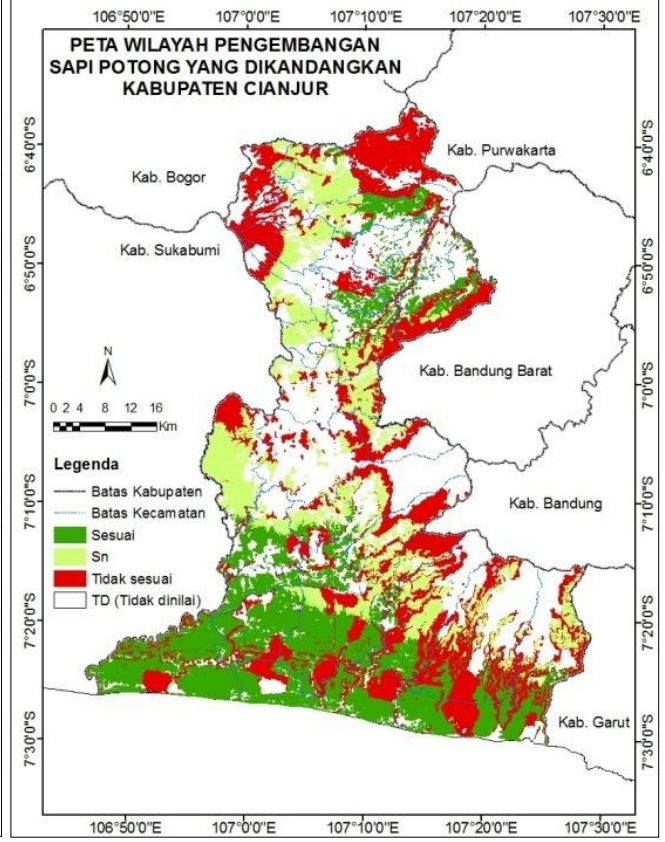

(b) Ternak yang dikandangkan

Gambar 3. Peta pengembangan peternakan sapi potong di Kabupaten Cianjur; (a) ternak yang digembalakan; (b) ternak yang dikandangkan 
Tabel 7. Luas wilayah pengembangan sapi potong yang dikandangkan di Kabupaten Cianjur

\begin{tabular}{|c|c|c|c|c|c|}
\hline \multirow{2}{*}{$\begin{array}{l}\text { Wilayah } \\
\text { pengembangan }\end{array}$} & \multicolumn{4}{|c|}{ Luas lahan (ha)* } & \multirow[b]{2}{*}{$\operatorname{Jumlah}(\mathbf{h a})^{*}$} \\
\hline & $\mathbf{S}$ & Sn & $\mathbf{N}$ & TD & \\
\hline Utara & $9,503.94(2.63 \%)$ & $28,961.73(8.01 \%)$ & $13,663.17(3.78 \%)$ & $56,106.41(15.51 \%)$ & $108,235.25$ \\
\hline Tengah & $9,131.40(2.52 \%)$ & $18,081.04(5.00 \%)$ & $14,025.94(3.88 \%)$ & $64,666.25(17.88 \%)$ & $105,904.63$ \\
\hline Selatan & $59,430.55(16.43 \%)$ & $34,921.77(9.66 \%)$ & $8,640.01(2.39 \%)$ & $44,514.95(12.31 \%)$ & $147,507.28$ \\
\hline Jumlah(ha)* & $78,065.89(21.59 \%)$ & $81,964.54(22.66 \%)$ & $36,329.12(10.05 \%)$ & $165,287.60(45.70 \%)$ & $361,647.15$ \\
\hline
\end{tabular}

*Luas merupakan penghitungan luas dari peta digital; S:Sesuai; Sn:Sesuai dengan pembatas THI; N:Tidak sesuai; TD:Tidak dinilai

\section{SIMPULAN}

1. Luas kesesuaian fisik lingkungan lahan untuk ternak sapi potong di Kabupaten Cianjur yang digembalakan adalah 193,282 ha $(53.45 \%)$ dalam status sesuai (S), sedangkan dan lahan yang tidak sesuai (N) seluas 3,076 ha $(0.85 \%)$. Wilayah yang sesuai (S) secara fisik lingkungan untuk peternakan sapi potong yang dikandangkan seluas 112,877 ha $(31.21 \%)$, lahan yang sesuai dengan pembatas THI (S-n) seluas 60,616 ha $(16.76 \%)$, dan lahan yang tidak sesuai (N) seluas 22,865 ha $(6.32 \%)$. Berdasarkan hal ini dapat dinyatakan bahwa Kabupaten Cianjur secara umum sesuai secara fisik lingkungan untuk peternakan sapi potong yang digembalakan dan dikandangkan.

2. Luas lahan yang sesuai (S) untuk hijauan makanan ternak (rumput Gajah, Setaria spachelata, rumput alam/pastura, dan leguminosa) di Kabupaten Cianjur adalah seluas 194,566 ha $(53.80 \%)$, sedangkan lahan yang tidak sesuai $(\mathrm{N})$ adalah 1,792 ha $(0.50 \%)$. Hal ini berarti bahwa beberapa wilayah di Kabupaten Cianjur sesuai untuk penanaman empat jenis hijauan makanan ternak.

3. Status daya dukung hijauan di Kabupaten Cianjur seluas 186,479 ha $(51.56 \%)$ adalah aman dan seluas 9,880 ha $(2.73 \%)$ berstatus rawan. Wilayah dengan status hijauan aman diprioritaskan sebagai wilayah pengembangan peternakan sapi potong terkait dengan memadainya ketersediaan hijauan. Berdasarkan kesesuaian fisik lingkungan, kesesuaian hijauan dan daya dukung hijauan makanan ternak maka wilayah Cianjur bagian selatan merupakan wilayah yang paling sesuai untuk pengembangan peternakan yang digembalakan dan dikandangkan.

4. Hasil-hasil analisis kesesuaian lingkungan fisik, kesesuaian hijauan dan status daya dukung hijauan tersebut kemudian digunakan untuk menetapkan wilayah yang sesuai untuk pengembangan ternak sapi potong yang dikandangkan dan digembalakan, yang disajikan secara spasial. Wilayah untuk pengembangan peternakan sapi potong yang digembalakan di Kabupaten Cianjur seluas 126,626 ha (35.01\%) dan untuk pengembangan peternakan sapi potong yang dikandangkan seluas 78,065 ha $(21.59 \%)$.

\section{UCAPAN TERIMA KASIH}

Penelitian ini merupakan bagian dari tesis penulis pertama pada Program Magister Perencanaan Wilayah IPB, atas sponsor dari Badan Perencanaan dan Pembangunan Nasional.

\section{DAFTAR PUTAKA}

Ashari, E. Juarini, Sumanto, B. Wibowo, Suratman, dan K. Diwyanto. 1996. Analisis Potensi Wilayah Penyebaran dan Pengembangan Peternakan. Balai Penelitian Ternak. Bogor.

Atmiyati. 2006. Daya dukung hijauan pakan terhadap pengembangan ternak di Kabupaten Sambas. Tетu Teknis Tenaga Fungsional Pertanian. Pusat Penelitian dan Pengembangan Peternakan. Bogor. hal 96-100.

[Bappeda] Badan Perencanaan dan Pembangunan Daerah Kabupaten Cianjur. 2011. Peta Kabupaten Cianjur Tahun 2011. Cianjur.

[BPS] Badan Pusat Statistik Kabupaten Cianjur. 2012. Kabupaten Cianjur dalam Angka. Cianjur.

Djaenudin, D., M. Hendrisman, Subagjo, dan A. Hidayat. 2003. Petunjuk Teknis Evaluasi Lahan untuk Komoditas Pertanian. Balai Penelitian Tanah, Puslitbangtanak, Badan Penelitian dan Pengembangan Pertanian. Bogor.

Hardjowigeno, S. dan Widiatmaka. 2007. Kesesuaian Lahan dan Perencanaan Tataguna Tanah. IPB. Bogor.

Herbut, P. and S. Angrecka. 2012. Forming of Temperature-Humidity Index (THI) and milk production of cow in the free-stall barn during the periode of summer heat. Animal Science Papers and Reports, 30: 363-372.

Kadarsih, S. 2004. Performans sapi Bali berdasarkan ketinggian tempat di daerah transmigrasi Bengkulu : I. Performans Pertumbuhan. Jurnal Ilmu-ilmu Pertanian Indonesia, 6: 50-56.

Rusmana, N., Atmiyati, dan Ridwan. 2006. Pembuatan Peta Kesesuaian Fisik lingkungan untuk Ternak Ruminansia pada Skala Tinjau. Balai Penelitian Ternak. Bogor.

Suherman, D., B.P. Purwanto, W. Manalu, dan I.G. Permana. 2013. Simulasi artificial neural network untuk menentukan suhu kritis pada sapi Fries Holland berdasarkan respon fisiologis. Jurnal Ilmu Ternak dan Veteriner, 18: 70-80.

Suratman, S. Ritung, dan D. Djaenudin. 1998. Potensi lahan untuk pengembangan ternak ruminansia besar 
di beberapa provinsi di Indonesia. Di dalam A.S. Karama (Ed.). Prosiding Pertemuan Pembahasan dan Komunikasi Hasil Penelitian Tanah dan Agroklimat. Bidang Pedologi. Cisarua. 1997 Maret 4-6. Pusat Penelitian Tanah dan Agroklimat, Bogor. hlm 169-182.

Thahar, A. and P. Mahyudin. 1993. Feed resource. In E.R. Teleni, S.F. Cambell, and D. Hoffman (Eds.). Draught Animal System and Management: An Indonesian Study. ACIAR, Canberra. pp. $41-50$.
Utomo, B., D.P. Miranti, dan G.C. Intan. 2009. Kajian termoregulasi sapi perah periode laktasi dengan introduksi teknologi peningkatan kualitas pakan. Prosiding Seminar Nasional Peternakan dan Veteriner. Bogor, 13-14 Agustus 2009. Pusat Penelitian dan Pengembangan Peternakan. Bogor. hlm $263-268$.

Yani, A., H. Suhardiyanto, R. Hasbullah, dan B.P. Purwanto. 2007. Analisis dan simulasi distribusi suhu udara pada kandang sapi perah menggunakan Computational Fluid Dynamics (CFD). Media Peternakan, 30: 218-228. 